\title{
ASSOCIATION OF HAPTOGLOBIN LEVELS WITH AGE, PARASITE DENSITY, AND HAPTOGLOBIN GENOTYPE IN A MALARIA-ENDEMIC AREA OFGABON
}

\author{
FREYA J. I. FOWKES, $\dagger$ HEATHER IMRIE, $\dagger$ FLORENCE MIGOT-NABIAS, PASCAL MICHON, ANITA JUSTICE, \\ PHILLIPE DELORON, ADRIAN J. F. LUTY, AND KAREN P. DAY* \\ Peter Medawar Building for Pathogen Research and Department of Zoology, University of Oxford, Oxford, United Kingdom; Institut \\ de Recherche pour le Développement, Dakar, Senegal; Papua New Guinea Institute of Medical Research, Madang, Papua New \\ Guinea; Institut de Recherche pour le Développement, Unité de Recherche 10 Mother and Child in the Tropics, Faculté de Pharmacie, \\ Paris, France; Human Parasitology, Institute for Tropical Medicine, University of Tübingen, Tübingen, Germany; Department of \\ Medical Parasitology, New York University, New York
}

\begin{abstract}
Haptoglobin ( $\mathrm{Hp}$ ) levels were investigated in relation to host genotype in a malaria-endemic area in Gabon. A cross-sectional study of 1-12-year-old children was conducted in the rainy season, a period of high malaria transmission, to examine this relationship. Variables that influenced Hp levels were Hp genotype, location, and age interacting with parasite density. At low parasite densities, there was a negative correlation between Hp levels and age. At higher densities, there was a positive correlation with age. This suggests that in the presence of greater parasiteinduced hemolysis, older children are capable of increased production of $\mathrm{Hp}$. Sickle cell trait and ABO blood group was not associated with $\mathrm{Hp}$ levels in this population.
\end{abstract}

\section{INTRODUCTION}

Haptoglobin (Hp) is an acute-phase protein that binds irreversibly to hemoglobin $(\mathrm{Hb})$, enabling its safe and rapid clearance. Therefore, Hp has an important protective role in hemolytic disease because it greatly reduces the oxidative and peroxidative potential of free $\mathrm{Hb} .^{1}$ Haptoglobin exists in three phenotypic forms: Hp 1-1, 2-1, and 2-2, which are encoded by two co-dominant alleles, $H p^{l}$ and $H p^{2}$. The $\mathrm{Hpl}$ allele can be further sub-typed into $\mathrm{HplF}$ and $\mathrm{HplS}^{2}$ The ability to bind $\mathrm{Hb}$ is phenotype dependent and has been found in the order of $1-1>2-1>2-2$, with the binding capacity reflecting the plasma levels of the various phenotypes. ${ }^{3}$ Functional differences between $\mathrm{HplF}$ and HplS are unknown. The Hp levels can be influenced by age, hemolysis, and particularly the acute-phase response. ${ }^{4}$

$\mathrm{Hp}$ is directly toxic to Plasmodium falciparum in vitro at concentrations that may occur during an acute-phase response. $^{3}$ The exact mechanism of action is not known. Hp does not enter the infected erythrocyte but may act indirectly, disrupting normal parasite protein trafficking within the host cell. ${ }^{\mathrm{s}}$ An in vivo model of malaria infection has demonstrated that parasite burdens and peak parasite densities were higher in $\mathrm{Hp}$ knockout mice. ${ }^{6}$ In addition, $\mathrm{Hp}$ is also antimicrobial; it makes iron unavailable to bacteria using $\mathrm{Hb}$, (e.g., Escherichia coli) and causes agglutination of Streptococcus pyogenes? $?^{8}$ Levels of $\mathrm{Hp}$ are reduced by both chronic, low level parasitemia and possibly malaria-associated immune complex destruction of infected erythrocytes, as well as clinical malaria. ${ }^{9,10}$

We recently demonstrated, in a malaria-endemic area of Papua New Guinea that individuals homozygous for $\mathrm{a}^{+}$thalassemia had increased levels of Hp compared with heterozygotes when harboring chronic parasitemia (Imrie $\mathrm{H}$. and others, unpublished data). We therefore decided to investigate whether the sickle cell trait influenced $\mathrm{Hp}$ levels in the face of malaria infection. Sickle cell $\mathrm{Hb}(\mathrm{HbS})$ is the most frequent abnormal $\mathrm{Hb}$ trait found in populations of African origin and is the result of an amino acid substitution on the (3 chain of $\mathrm{Hb} .{ }^{11}$ Individuals who are homozygous (HbSS) for

$\dagger$ These authors contributed equally to this work.

* Address correspondence to Karen P. Day, Department of Medical Parasitology, New York University School of Medicine, 341 East 25th Street, New York, NY 10010. E-mail: karen.day@med.nyu.edu the $\mathrm{HbS}$ variant of $\mathrm{Hb}$ have severe consequences of sickle cell disease, whereas HbAS carriers have been shown to enjoy substantial protection against severe $P$. falciparum malaria compared with $\mathrm{HbAA}$ individuals. ${ }^{12}$ The mechanism by which $\mathrm{HbAS}$ affords protection is yet to be elucidated. Studies on differences in hematologic parameters between normal $\mathrm{Hb}$ genotypes (HbAA) and sickle cell trait (HbAS) have been inconsistent. ${ }^{13}$

To date, Hp levels have not been directly measured in relation to sickle cell genotype in a malaria-endemic area. One previous study investigated the association between prevalence of ahaptoglobinemia and $\mathrm{HbS}$ and found no correlation. ${ }^{14}$ We conducted a cross-sectional study in children living in southeast Gabon to examine the relationship of host genotype and $\mathrm{Hp}$ levels in a malaria-endemic area. The prevalence rates of three genetic polymorphisms, Hp genotype, sickle cell trait, and ABO blood group, as well as parasitologic criteria, were determined. The relationships between these variables and median $\mathrm{Hp}$ levels are presented in this report.

\section{MATERIALS AND METHODS}

Study area. The study was conducted in two villages (Dienga and Bakoumba) in southeast Gabon near the Congo border. Malaria is highly endemic with peaks of transmission at the end of the rainy seasons (September-December and March-June). ${ }^{15}$ A cross-sectional survey was conducted in May-June in 2000 in a cohort of 641 asymptomatic children 1-12 years of age. This study was initially designed to investigate antibody properties in relation to erythrocyte polymorphisms. Details on the study population and data collection procedures have been published elsewhere. ${ }^{16}$ Briefly, after obtaining informed consent from all individuals and/or their parents, venous blood was collected in tubes containing EDTA for parasitologic assessment, genotyping of the sickle cell trait, and determination of ABO blood group. Unsuccessful $\mathrm{Hb}$ phenotyping was due to an insufficient volume of sample rather than technical problems. The study was reviewed and approved by the ethics committee of the International Center for Medical Research of Franceville.

Parasitologic measurements. Parasite densities were counted per 500 leukocytes on Giemsa-stained thick blood smears, and were recorded as the number of parasites per 
microliter of blood, assuming an average leukocyte count of $8,000 /$ (xL. ${ }^{17}$ Duplicate readings were made for a random $15 \%$ of smears to ensure quality control.

Plasma Hp levels. Plasma Hp levels were determined by an enzyme-linked immunosorbent assay (ELISA) using 96-well plates coated with rabbit anti-human Hp (H-8636; Sigma, St. Louis, MO) as capture antibody and monoclonal anti-human Hp (H-6395; Sigma) as detection antibody. Immunoplates (F96 maxisorp; Nunc, Roskilde, Denmark) were coated overnight at $4^{\circ} \mathrm{C}$ with rabbit anti-human $\mathrm{Hp}$ (H-8636; Sigma) capture antibody diluted in phosphate-buffered saline (PBS) to a final concentration of 30 (xg/mL (100 (xL/well). Blank wells were coated with PBS alone. Wells were washed three times with 200 (xL/well of PBS. Bovine serum albumin (BSA) (3\%) in PBS was used to block the wells (200 (xL/well for 1 hour at room temperature). Samples were diluted 1:10,000 in $3 \%$ BSA/PBS and Hp standards (100 ng/mL, $80 \mathrm{ng} / \mathrm{mL}, 60 \mathrm{ng} / \mathrm{mL}$, $40 \mathrm{ng} / \mathrm{mL}, 20 \mathrm{ng} / \mathrm{mL}$, and $0 \mathrm{ng} / \mathrm{mL}$ ) prepared using pooled $\mathrm{Hp}$ (Sigma) in $3 \%$ BSA/PBS. Aliquots of 100 (xL were added to wells in duplicate, incubated for 1 hour at room temperature, and washed three times in PBS-Tween 20 (subsequent incubations and washes were similar). Detection was made with monoclonal anti-Hp (H-6395; Sigma) diluted in 3\% BSA/PBS (final concentration $=11.7(\mathrm{xg} / \mathrm{mL})$, followed by sheep antimouse IgG alkaline phosphatase conjugate (A3563; Sigma) diluted 1:30,000 in 3\% BSA/PBS. The substrate used was p-nitrophenyl phosphate (Sigma) $1 \mathrm{mg} / \mathrm{mL}$ in $10 \%$ diethanolamine, $\mathrm{pH}$ 9.8, containing $0.5 \mathrm{mM} \mathrm{MgCl}_{2}, 100$ (xL/well. Samples were incubated in the dark at room temperature and read at $405 \mathrm{~nm}$. A standard curve was made from which sample levels were read and multiplied by the dilution factor, giving sample $\mathrm{Hp}$ concentrations of $0 \mathrm{mg} / \mathrm{mL}$ or within the range $0.01-1 \mathrm{mg} / \mathrm{mL}$. Samples with $>1 \mathrm{mg} / \mathrm{mL}$ were diluted appropriately before repeating the ELISA.

Human genetic factors. Blood group was determined by serologic analysis and the sickle cell trait was detected by $\mathrm{Hb}$ electrophoresis. ${ }^{18}$ The $\mathrm{Hp}$ genotype was determined by a polymerase chain reaction (PCR) using a method previously described with modifications. ${ }^{19}$ The DNA was extracted from blood spots on filter paper using the QIAamp DNA Mini kit (Qiagen, Valencia, CA). Three PCRs were performed on each sample to genotype the Hp1S, $1 \mathrm{~F}$, and 2 alleles using forward primers C51, 5'-GCA ATG ATG TCA CGG ATA TC-3' and F3, 5'-CAG GAG TAT ACA CCT TAA ATG-3' and reverse primers $\mathrm{C} 42$, 5'-TTA CAC TGG TAG CGA ACC GA-3', C72, 5'-AAT TTA AAA TTG GCA TTT CGC C-3' and S2, 5'-TTA TCC ACT GCT TCT CAT TG-3'. The combination of $\mathrm{F} 3$ and $\mathrm{C} 42$ identified the $\mathrm{Hp} 2$ allele, $\mathrm{C} 51$ and $\mathrm{S} 2$ the Hp1S allele, and F3 and $\mathrm{C} 72$ the $\mathrm{Hp} 1 \mathrm{~F}$ allele. The PCR was performed using 0.025 units/jxL of HotStar Taq DNA polymerase (Qiagen) with supplied buffer, oligonucleotide primers (400 nM each), and dNTPs (200 (xM each). The temperature cycles used were $94^{\circ} \mathrm{C}$ for 15 minutes, 35 cycles at $94^{\circ} \mathrm{C}$ for 40 seconds, $52^{\circ} \mathrm{C}$ for 1 minute for the C51-S2 and $\mathrm{F} 3-\mathrm{C} 72$ reactions and $58^{\circ} \mathrm{C}$ for 1 minute for the $\mathrm{F} 3-\mathrm{C} 42$ reactions, and $72^{\circ} \mathrm{C}$ for 2 minutes. Products of $1,400,1,200$, and 935 basepairs were obtained for the $\mathrm{Hp} 1 \mathrm{~F}, \mathrm{Hp} 1 \mathrm{~S}$, and $\mathrm{Hp} 2$ alleles, respectively.

Statistical analysis. Missing value analysis and frequency distribution analysis was assessed by chi-square tests. The association between categoric variables and parasite density was assessed using Kruskal-Wallis tests. A general linear model was used to examine the effect of variables of interest on Hp levels. Since Hp levels showed heteroscedasticity (nonconstancy of the variance), they were transformed before analysis using the transformation $\log (\mathrm{Hp}+0.0015)$. This was chosen by examining profile likelihoods. ${ }^{20}$ The model was developed using R 1.6.2 (R Foundation for Statistical Computing, Vienna, Austria) and stepwise fitting with Akaike information criterion using a dataset that omitted all subjects for whom any data was missing. ${ }^{20}$ The full model examined the effect of age (continuous or three categories [1-4, 5-9, and 10-12 years of age]), Plasmodium density (log(Plasmodium + 1) and 4 categories: 0, 1-99, 100-1,000, and >1000 parasites/ (xL), P. malariae and P. falciparum positivity (two categories), location, Hp genotype (three categories and six categories), sex, ABO blood groups together with sickle cell phenotype, and interactions between variables. Four hundred eightyeight subjects from a cohort of 641 children 1-12 years of age were included in the final analysis. Exclusions included subjects who could not be phenotyped for sickle cell $(\mathrm{n}=52)$, subjects whose Hp levels could not be determined ( $\mathrm{n}=78$ ) missing values $(n=11)$, outliers $(n=8)$ and, due to small numbers, HbSS $(\mathrm{n}=4)$. The final model was refitted to all data and variables with $P$ values $>0.05$ were removed. SPSS for Windows version 11.5 (SPSS, Inc., Chicago, IL) was used for initial examination of the data and for the final stage of the analysis.

\section{RESULTS}

This study investigated the association between host genotype and Hp levels together with parasitologic factors in a malaria-endemic area. A total of 641 asymptomatic children 1-12 years of age were recruited into the study. The Hp levels and sickle cell phenotype was successfully determined in 511 subjects. There was no statistical difference between the 511 children included in this analysis and those who were not included with respect to any of the other variables $(P>0.05)$. The genotypic, parasitologic, and other frequencies of variables of these 511 children are shown in Table 1.

The study population, which was composed of equal numbers of males and females, had only four children $(0.8 \%)$ with the HbSS genotype; whereas $79.6 \%$ had the HbAA genotype. Approximately half $(52.6 \%)$ the subjects were blood group $\mathrm{O}$. These genetic frequencies are consistent with other studies done in the same area. ${ }^{18}$ Two hundred thirty-four children $(45.8 \%)$ were slide negative for any species of Plasmodium. Of those who were positive, approximately half had greater than 100 parasites/jxL of blood. The dominant species was $P$. falciparum, which was found in $51.7 \%$ of the cohort. The median parasite count (range) according to age group was as follows: 1-4 years of age, 0 (0-200,000) parasites/jxL; 5-9 years of age, $107(0-58,560)$ parasites/(xL; and 10-12 years of age, $160(0-14,400)$ parasites/jxL. There was no significant association between age group and parasite prevalence $(P=$ $0.13)$ or parasite density $(P=0.99)$. The median Hp level (range) of the 511 samples was $0.125(0.0-3.35) \mathrm{mg} / \mathrm{mL}$. Four individuals were ahaptoglobinemic. There was no association between any of the malariometric indices and host genotype with respect to $\mathrm{Hb}$ phenotype $(P>0.1)$.

A general linear model was used to examine the effect of variables of interest on transformed $\mathrm{Hp}$ levels in samples from the cohort. The resulting fitted model predicts the me- 
TABLE 1

Genetic, demographic, and parasitologic characteristics of 511 children successfully genotyped for hemoglobin $\mathrm{S}^{*}$

Variable

\begin{tabular}{|c|c|}
\hline \multirow{2}{*}{\multicolumn{2}{|c|}{$\begin{array}{l}\text { Haptoglobin, median (range), } \mathrm{mg} / \mathrm{mL} \\
\text { Sickle cell genotype }\end{array}$}} \\
\hline & \\
\hline $\mathrm{A} / \mathrm{A}$ & 407 (79.6) \\
\hline $\mathrm{A} / \mathrm{S}$ & $100(19.6)$ \\
\hline $\mathrm{S} / \mathrm{S}$ & $4(0.8)$ \\
\hline \multicolumn{2}{|l|}{$\mathrm{ABO}$ blood group $\dagger$} \\
\hline A & $132(25.8)$ \\
\hline B & $87(17.0)$ \\
\hline $\mathrm{AB}$ & $15(2.9)$ \\
\hline $\mathrm{O}$ & $269(52.6)$ \\
\hline \multicolumn{2}{|l|}{ Haptoglobin genotype } \\
\hline $1 \mathrm{~F}-1 \mathrm{~F}$ & $84(16.4)$ \\
\hline $1 \mathrm{~S}-1 \mathrm{~F}$ & $83(16.2)$ \\
\hline $1 \mathrm{~S}-1 \mathrm{~S}$ & $20(3.9)$ \\
\hline $2-1 \quad 1 \mathrm{~F}-2$ & $168(32.9)$ \\
\hline $1 \mathrm{~S}-2$ & 75 (14.7) \\
\hline $2-2$ & $81(15.9)$ \\
\hline \multicolumn{2}{|l|}{ Sex } \\
\hline Male & $265(51.9)$ \\
\hline \multicolumn{2}{|l|}{ Age groups, years $\dagger$} \\
\hline $1-4.9$ & $147(28.8)$ \\
\hline $5-9.9$ & $295(57.7)$ \\
\hline $10-12$ & $58(11.4)$ \\
\hline \multicolumn{2}{|l|}{ Location } \\
\hline Dienga & $33(6.5)$ \\
\hline Bakoumba & $478(93.5)$ \\
\hline \multicolumn{2}{|l|}{ Plasmodium density, $[\mathrm{xL} \dagger$} \\
\hline 0 & $234(45.8)$ \\
\hline $1-99$ & $27(5.3)$ \\
\hline 100-999 & $121(23.7)$ \\
\hline$>1,000$ & $126(24.7)$ \\
\hline P. falciparum positive & $264(51.7)$ \\
\hline P. malariae positive & $24(4.7)$ \\
\hline
\end{tabular}

* Values are no. $(\%)$ unless otherwise indicated.

$\dagger$ Some values are missing.

dian Hp level for the population controlling for relevant variables. After exclusions, 488 subjects were included in the final model. The final model chosen included location, Hp genotype, and parasite density interacting with age. The Hp levels did not significantly vary with sickle cell phenotype $(P>0.05)$. Median levels (95\% confidence interval $[\mathrm{CI}]$ ) in children with the HbAA phenotype were $0.122(0.105,0.141) \mathrm{mg} / \mathrm{mL}$ compared with $0.128(0.095,0.172) \mathrm{mg} / \mathrm{mL}$ in HbAS children. There was no significant difference in median Hp levels between $\mathrm{ABO}$ blood group, sex, or parasite positivity $(P>0.05)$.

The Hp levels were higher in samples from Bakoumba compared with those from Dienga $(P<0.001)$. The model also predicts a difference in median $\mathrm{Hp}$ level between the different Hp genotypes with higher levels in 1-1 $(0.115$ [95\% $\mathrm{CI}=0.085,0.157] \mathrm{mg} / \mathrm{mL})$ compared with $2-1(0.057[0.042$, $0.077] \mathrm{mg} / \mathrm{mL})$ and $2-2(0.058[0.039,0.085] \mathrm{mg} / \mathrm{mL})$ (overall $P$ $<0.001)$. There was no significant difference between the different $1 \mathrm{~F}$ and $1 \mathrm{~S}$ subtypes of $1-1$ and $2-1(P>0.3)$. The Hp level decreased with increasing parasite density $(P<0.001)$. There was no significant effect of age as a main effect in the model $(P=0.21)$. However, there was evidence of an interaction between age and parasite density $(P=0.001)$. Figure 1 shows that in low level infection ( 0 and 1-99 parasites/(xL), Hp levels decrease with age $(r=-0.57$ and $r=-0.76$, respectively). In high parasitemic infections (100-999 and > 1,000 parasites/(xL), the Hp level increased with age $(r=0.61$ and $\mathrm{r}=0.65$, respectively).

\section{DISCUSSION}

In malaria-endemic areas, low levels of $\mathrm{Hp}$ reflect recent parasitemia and malaria-induced hemolysis, as well as transmission intensity. ${ }^{21}$ Levels of $\mathrm{Hp}$ in this study were low compared with Caucasians and Africans without malaria but comparable to those of asymptomatic malaria-infected populations in Africa. ${ }^{10,22-24}$ The prevalence of ahaptoglobinemia was low compared to other studies, where prevalences of 20$50 \%$ were found. ${ }^{9},{ }^{14},{ }^{21},{ }^{25-34}$ This discrepancy can be explained by the different methodologies used to define ahaptoglobinemia. In our study, the sensitivity of the ELISA was high and we were able to detect Hp levels as low as $0.01 \mathrm{mg} / \mathrm{mL}$. Earlier studies used either protein electrophoresis to determine phenotype or an ELISA in which the lower limit of detection was $0.05 \mathrm{mg} / \mathrm{mL}$. A total of $34.2 \%$ of our population had $\mathrm{Hp}$ levels $<0.05 \mathrm{mg} / \mathrm{mL}$, which is consistent with the aforementioned studies.

In this population, Hp levels were associated with Hp genotype, location, and age interacting with parasite density. As expected, the Hp levels were higher in the 1-1 genotype compared with 2-1 and 2-2. ${ }^{2}$ Children from the Dienga region had lower Hp levels than children in Bakoumba, which reflected differences in transmission. During the rainy season, the entomologic inoculation rates in Bakoumba and Dienga are 0.83 and 0.91 infective bites/person/night, respectively. ${ }^{15},{ }^{35}$ The Hp levels were significantly negatively correlated with parasite density. This finding is consistent with a study performed in Tanzania, ${ }^{10}$ although another study in The Gambia showed no association between parasite density and Hp levels. ${ }^{36}$

The finding of most interest in our study was the interaction between parasite density and age. At negative or low parasitemias $(<100$ parasites/jxL), Hp levels decreased with age. In contrast, at higher parasitemias ( $>100$ parasites/jxL), Hp levels increased with age. All age groups experienced the full range of parasite densities, so it is unlikely that age distribution within each parasite category biased the results.

The inverse relationship between age and $\mathrm{Hp}$ in noninfected subjects is similar to that seen in non-malarious populations of the same age, although the reason for this is unknown. ${ }^{37},{ }^{38}$ In parasitized subjects, it is known that a positive correlation exists between interleukin-6 (IL-6)-dependent C-reactive protein (CRP) and parasite density. ${ }^{10},{ }^{23}, 36,39$ An interaction between age and parasite density is yet to be investigated with respect to CRP or other acute-phase proteins.

The interaction in our data indicate that $\mathrm{Hp}$ production is activated relative to the level of malaria-induced hemolysis. Older children may have an enhanced response to this hemolysis by increasing production of $\mathrm{Hp}$ induced by IL- $6{ }^{40} \mathrm{It}$ is possible that the improvement of the acquired immune response, together with the acute-phase response with age, enables Hp production to be enhanced during the mass hemolysis that occurs during high-density infections. The interaction between acquired and innate immunity could provide an explanation for the interaction between parasite density and age.

This study also examined the affect of the HbAS phenotype on median levels of Hp. It might be expected that this trait alters Hp levels due to its effects on levels of hemolysis. This may occur by increased erythrocyte turnover in the HbAS genotype because of altered $\mathrm{Hb}$ structure or decreased turnover of erythrocytes because of reduced levels of para- 

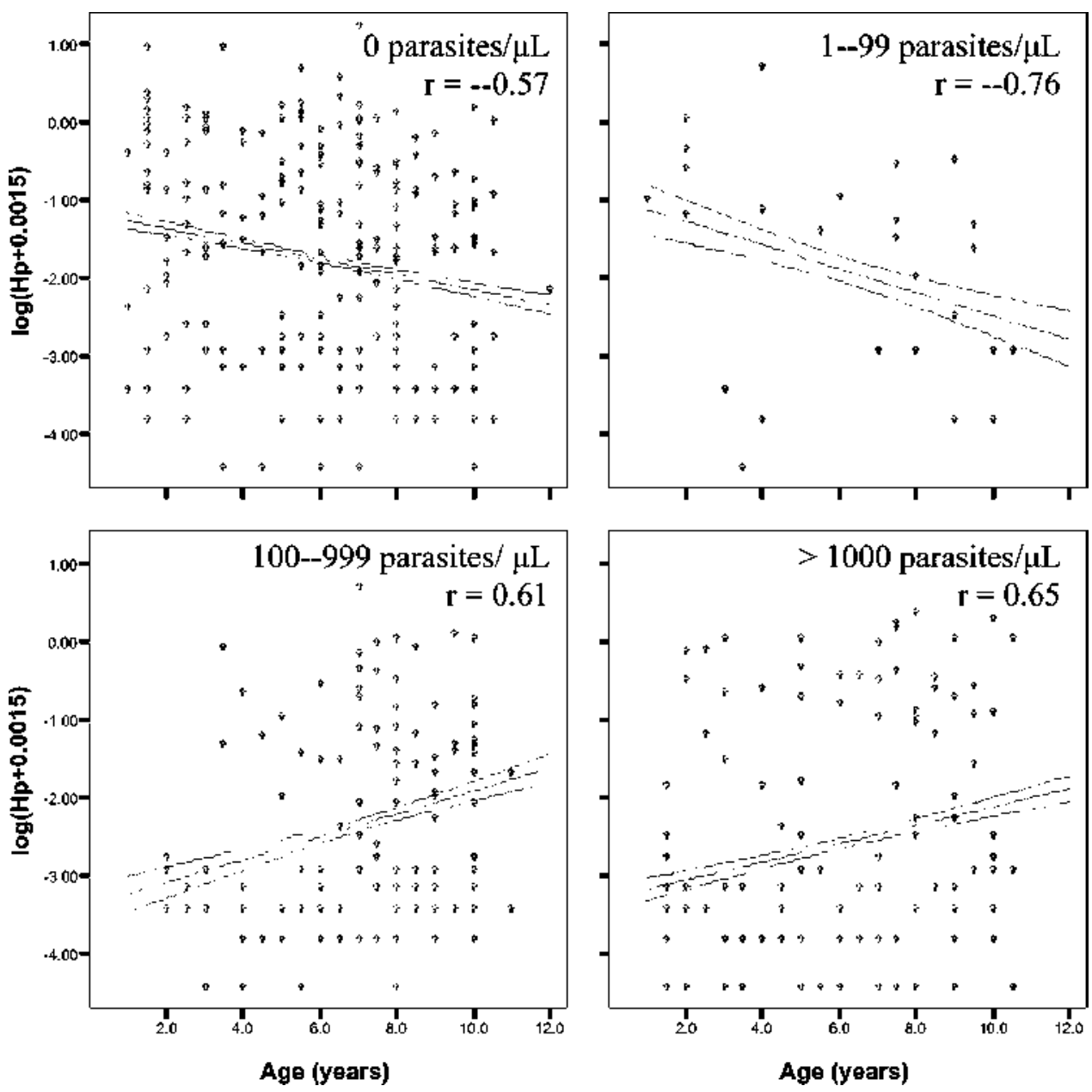

FIGURE 1. General linear model showing evidence of interaction between age and parasite density $(P=0.001)$. Haptoglobin $($ Hp) levels are associated with parasite density and age. At low parasite densities $(<100$ parasites/|xL), Hp (transformed data) is negatively correlated with age, but at high parasite densities (> 100 parasites/|xL), Hp is positively correlated with age. Lines represent predicted Hp values with $95 \%$ confidence interval from modeled data, i.e., controlling for relevant variables. Dots represent unmodeled data.

sitemia in this protective genotype. ${ }^{41}$ This study did not demonstrate a significant difference between median $\mathrm{Hp}$ levels and $\mathrm{HbS}$ phenotype. This result is also consistent with our finding of no evidence of increased parasitemia in either $\mathrm{HbAA}$ or HbAS phenotype and provides further evidence of indistinguishable hematologic parameters between these two phenotypes.

Collection of samples took place during the wet season when parasite burdens are high. High parasitemias could mean that all subjects, regardless of $\mathrm{Hb}$ genotype, have very low levels of $\mathrm{Hp}$ due to high levels of hemolysis and clearance of the $\mathrm{Hp}-\mathrm{Hb}$ complex. To fully investigate the effect of $\mathrm{Hb}$ genotype on $\mathrm{Hp}$ levels, and its potential role in malaria, repeating the survey would be required during a period of low transmission or in another country where malaria transmission is strictly seasonal. The interaction of parasite density with age warrants further investigation into the role of $\mathrm{Hp}$ and other acute phase proteins in the protection against malaria.

Received January 18, 2005. Accepted for publication August 29, 2005.

Acknowledgments: We are grateful to the children and their families of Bakoumba and Dienga for their willing participation in the study. We thank Justice Mayombo, Faustin Lekoulou, and Hubert Mou- kana for excellent technical assistance and Dr. René Nabias for determination of $\mathrm{ABO}$ blood groups and hemoglobin phenotypes. We also thank Jean Bourgeais, (Societe d'Exploitation des Produits Alimentaires) for his logistical support in Bakoumba.

Financial support: This study was supported by The Wellcome Trust and the European Union INCO Programme (contract no. IC18CT98-0359).

Authors' addresses: Freya J. I. Fowkes and Karen P. Day, Department of Medical Parasitology, New York University School of Medicine, 341 East 25th Street, New York, NY 10010, Telephone: 212263-6800, Fax: 212-263-8116, E-mails: freya.fowkes@med.nyu .edu and karen.day@med.nyu.edu. Heather Imrie and Anita Justice, Peter Medawar Building for Pathogen Research, Department of Zoology, South Parks Road, Oxford University, Oxford, OX1 3SY, United Kingdom, E-mails: heather.imrie@medawar.ox.ac.uk and neatsey@ hotmail.com. Florence Migot-Nabias, Institut de Recherche pour le Développement, Unité de Recherche 10, BP 1386, CP 18524 Dakar, Senegal, Telephone: 221-849-36-11, Fax: 221-832-43-07, E-mail: migot@ndakaru.ird.sn. Pascal Michon, Papua New Guinea Institute of Medical Research, P.O. Box 378, Madang 511, Papua New Guinea, Telephone: 675-852-2909, Fax: 675-852-3289, E-mail: pmichon@ datec.net.pg. Philippe Deloron, Institut de Recherche pour le Développement, Unité de Recherche 10 Mother and Child in the Tropics, Faculté de Pharmacie, 4 Avenue de l'Observatoire, 75006 Paris, France, Telephone: 33-1-53-73-96-22, Fax: 33-1-53-73-96-17, E-mail: philippe.deloron@ird.fr. Adrian J. F. Luty, Medical Parasitology, De- 
partment of Medical Microbiology, University Medical Centre, St. Radboud, P.O. Box 9101, 6500 HB Nijmegen, The Netherlands, E-mail: a.luty@mmb.umcn.nl.

Reprint requests: Karen P. Day, Department of Medical Parasitology, New York University School of Medicine, 341 East 25th Street, New York, NY 10010

\section{REFERENCES}

1. Lim SK, Ferraro B, Moore K, Halliwell B, 2001. Role of haptoglobin in free hemoglobin metabolism. Redox Rep 6: 219-227.

2. Langlois MR, Delanghe JR, 1996. Biological and clinical significance of haptoglobin polymorphism in humans. Clin Chem 42: $1589-1600$.

3. Okazaki T, Nagai T, 1997. Difference in hemoglobin-binding ability of polymers among haptoglobin phenotypes. Clin Chem 43: 2012-2013.

4. Dobryszycka W, 1987. Przydatnosc oznaczen haptoglobiny w diagnostyce laboratoryjnej. Diagnostika Laboratoryjna 23: 117-135.

5. Imrie H, Ferguson D, Day KP, 2004. Human serum haptoglobin is toxic to Plasmodium falciparum in vitro. Mol Biochem Parasitol 133: 93-98.

6. Hunt NH, Driussi C, Sai-Kiang L, 2001. Haptoglobin and malaria. Redox Rep 6: 389-392.

7. Eaton JW, Brandt P, Mahoney JR, Lee JT Jr, 1982. Haptoglobin: a natural bacteriostat. Science 215: 691-693.

8. Delanghe J, Langlois M, Ouyang J, Claeys G, De Buyzere M, Wuyts B, 1998. Effect of haptoglobin phenotypes on growth of Streptococcus pyogenes. Clin Chem Lab Med 36: 691-696.

9. Trape JF, Fribourg-Blanc A, Bosseno MF, Lallemant M, Engler R, Mouchet J, 1985. Malaria, cause of ahaptoglobinaemia in Africans. Trans $R$ Soc Trop Med Hyg 79: 430-434.

10. McGuire W, D'Alessandro U, Olaleye BO, Thomson MC, Langerock P, Greenwood BM, Kwiatkowski D, 1996. Creactive protein and haptoglobin in the evaluation of a community-based malaria control programme. Trans $R$ Soc Trop Med Hyg 90: 10-14.

11. Ashley-Koch A, Yang Q, Olney RS, 2000. Sickle hemoglobin (HbS) allele and sickle cell disease: a HuGE review. Am J Epidemiol 151: 839-845.

12. Greenwood BM, Marsh K, Snow RW, 1991. Why do some African children develop severe malaria? Parasitol Today 7: 277-281.

13. Steinberg M, 2001. Sickle cell trait. Steinburg M, Forget B, Higgs D, Nagel RL, eds. Disorders of Hemoglobin: Genetics, Pathophysiology and Clinical Management. Cambridge, United Kingdom: Cambridge University Press, 811-830.

14. Boreham PF, Lenahan JK, Port GR, McGregor IA, 1981. Haptoglobin polymorphism and its relationship to malaria infections in The Gambia. Trans R Soc Trop Med Hyg 75: 193-200.

15. Elissa N, Migot-Nabias F, Luty A, Renaut A, Toure F, Vaillant M, Lawoko M, Yangari P, Mayombo J, Lekoulou F, Tshipamba P, Moukagni R, Millet P, Deloron P, 2003. Relationship between entomological inoculation rate, Plasmodium falciparum prevalence rate, and incidence of malaria attack in rural Gabon. Acta Trop 85: 355-361.

16. Ntoumi F, Ekala MT, Makuwa M, Lekoulou F, MercereauPuijalon O, Deloron P, 2002. Sickle cell trait carriage: imbalanced distribution of IgG subclass antibodies reactive to Plasmodium falciparum family-specific MSP2 peptides in serum samples from Gabonese children. Immunol Lett 84: 9-16.

17. Cox MJ, Kum DE, Tavul L, Narara A, Raiko A, Baisor M, Alpers MP, Medley GF, Day KP, 1994. Dynamics of malaria parasitaemia associated with febrile illness in children from a rural area of Madang, Papua New Guinea. Trans $R$ Soc Trop Med Hyg 88: 191-197.

18. Migot-Nabias F, Mombo LE, Luty AJ, Dubois B, Nabias R, Bisseye C, Millet P, Lu CY, Deloron P, 2000. Human genetic factors related to susceptibility to mild malaria in Gabon. Genes Immun 1: 435-441.

19. Yano A, Yamamoto Y, Miyaishi S, Ishizu H, 1998. Haptoglobin genotyping by allele-specific polymerase chain reaction amplification. Acta Med Okayama 52: 173-181.

20. Venables W, Ripley B, 2002. Modern Applied Statistics with S. New York: Springer-Verlag.
21. Trape JF, Fribourg-Blanc A, 1988. Ahaptoglobinemia in African populations and its relation to malaria endemicity. Am J Epidemiol 127: 1282-1288.

22. Kasvosve I, Gomo Zvenyika AR, Gangaidzo Innocent T, Mvundura E, Saungweme T, Moyo Victor M, Khumalo H, Boelaert Johan R, Gordeuk Victor R, Delanghe Joris R, 2000. Reference range of serum haptoglobin is haptoglobin phenotypedependent in blacks. Clin Chim Acta 296: 163-170.

23. Jakobsen PH, McKay V, N'Jie R, Olaleye BO, D'Alessandro U, Zhang GH, Eggelte TA, Koch C, Greenwood BM, 1998. Decreased antitoxic activities among children with clinical episodes of malaria. Infect Immun 66: 1654-1659.

24. Sisay F, Byass P, Snow RW, Greenwood BM, Perrin LH, Yerly S, 1992. Measurement of serum haptoglobin as an indicator of the efficacy of malaria intervention trials. Trans $R$ Soc Trop Med Hyg 86: 14-16.

25. Allison A, Blumberg B, Rees A, 1958. Haptoglobin types in British, Spanish Basque and Nigerian African populaitons. Nature 181: 824-825.

26. Barnicot NA, Garlick JP, Roberts DF, 1960. Haptoglobin and transferrin inheritance in northern Nigerians. Ann Hum Genet 24: $171-183$

27. Blumberg B, Gentile Z, 1961. Haptoglobins and transferrins of two tropical populations. Nature 189: 897-899.

28. Lefèvre-Witier P, 1974. Structure génétique des systèmes sanguins érythrocytaires et sériques chez les Kel Kummer. Рориlation 29: 517-527.

29. Rougemont A, Quilici M, Delmont J, Ardissone JP, 1980. Is the $\mathrm{HpO}$ phenomenon in tropical populations really genetic? Hum Hered 30: 201-203.

30. Neel JV, Robinson AR, Zuelzer WW, Livingstone FB, Sutton HE, 1961. The frequency of elevations in the A and fetal hemoglobin fractions in the natives of Liberia and adjacent regions, with data on haptoglobin and transferrin types. Am J Hum Genet 13: 262-278.

31. Giblett ER, Motusky AG, Fraser GR, 1966. Population genetic studies in the Congo. IV. Haptoglobin and transferrin serum groups in the Congo and in other African populations. Am J Hum Genet 18: 553-558.

32. Moullec J, Kane Y, Ruffie J, Nguyenvan C, 1964. Haptogobin and transferring groups in 4 samples of the Senegal population. Transfusion (Paris) 61: 161-164.

33. Vu Tien J, Pison G, Levy D, Darcos JC, Constans J, Bernard J, 1975. Quantitative study of the genetics of haptoglobin levels C R Acad Sci Hebd Seances Acad Sci D 280: 2417-2419.

34. Allison AC, Barnicot NA, 1960. Haptoglobins and transferrins in some East African peoples. Acta Genet Stat Med 10: 17-23.

35. Aubouy A, Migot-Nabias F, Deloron P, 2003. Polymorphism in two merozoite surface proteins of Plasmodium falciparum isolates from Gabon. Malar J 2: 12.

36. Hurt N, Smith T, Tanner M, Mwankusye S, Bordmann G, Weiss NA, Teuscher T, 1994. Evaluation of C-reactive protein and haptoglobin as malaria episode markers in an area of high transmission in Africa. Trans $R$ Soc Trop Med Hyg 88:182-186.

37. Ritchie RF, Palomaki GE, Neveux LM, Navolotskaia O, Ledue TB, Craig WY, 1999. Reference distributions for the negative acute-phase serum proteins, albumin, transferrin and transthyretin: a practical, simple and clinically relevant approach in a large cohort. J Clin Lab Anal 13: 273-279.

38. Ritchie RF, Palomaki GE, Neveux LM, Navolotskaia O, Ledue TB, Craig WY, 2000. Reference distributions for the positive acute phase serum proteins, alpha1-acid glycoprotein (orosomucoid), alpha1-antitrypsin, and haptoglobin: a practical, simple, and clinically relevant approach in a large cohort. $J$ Clin Lab Anal 14: 284-292.

39. Hurt N, Smith T, Teuscher T, Tanner M, 1994. Do high levels of $\mathrm{C}$-reactive protein in Tanzanian children indicate malaria morbidity. Clin Diagn Lab Immunol 1: 437-444.

40. Raynes JG, Eagling S, McAdam KP, 1991. Acute-phase protein synthesis in human hepatoma cells: differential regulation of serum amyloid A (SAA) and haptoglobin by interleukin-1 and interleukin-6. Clin Exp Immunol 83: 488-491.

41. Al-Shakour AA, Al-Suhail AA, 2000. Percentage of HbS among cases of sickle-cell trait in Basra, Iraq. East Mediterr Health $J$ 6: 233-237. 